\title{
Effect of (2-Chloroethyl)trimethylammonium Chloride on the Formation and Dormancy of Aerial Tubers of Begonia evansiana*
}

\author{
by Masayuki NAGAO** and Nobuo OKAGAMI**
}

Received August 13, 1966

Begonia evansiana forms aerial tubers in response to short-day (SD) treatment ${ }^{1,2)}$. The full-grown tubers enter a dormant state and require low temperature treatment for their sprouting ${ }^{3)}$. There are many instances in which gibberellin (GA) can break dormancy in the buds or seeds of many species of plants ${ }^{4,5}$. However, GA has no such effect in the case of Begonia tubers; contrarily, it prolongs or induces their dormancy ${ }^{6}$. Rapidly growing, immature tubers, which can sprout when detached and incubated in the light, also become dormant by GA treatment ${ }^{7,8)}$.

On the other hand, tuberization to be caused under SDs is inhibited and the bud begins to sprout when the plant is treated with GA within the first several days of the SD treatment, whereas the GA treatment given in a later period has little effect on the size of the tubers formed and these tubers enter a dormant state more rapidly ${ }^{7,8)}$.

GA-induced dormancy is broken by low temperature treatment as in the case of natural dormancy ${ }^{6,8)}$. Native GA-like substance(s) is detectable in the buds of the Begonia plants grown under long-day (LD) conditions. Its amount seems to show a decrease at first and then an increase during the tuber development under SDs ${ }^{9}$.

All the facts mentioned above strongly suggest that the native GA may play some role in the tuberization process in Begonia evansiana. It is supposed that the lowering of the endogenous GA level and its subsequent rise under SDs seem to be necessary for the tuber initiation and the induction of tuber dormancy, respectively.

The present experiments with (2-chloroethyl)trimethylammonium chloride (CCC), which is reported to inhibit the biosynthesis of GA, were carried out to give a further support for the above supposition.

\section{Material and Methods}

All the experiments were performed with the single-noded cuttings of Begonia evansiana. They were prepared according to the procedures essentially similar to those described by Esashi ${ }^{10}$. In brief, they were obtained by cutting the stem immediately above and about $15 \mathrm{~cm}$ below the node bearing a nearly mature leaf, and cultured in the modified Hoagland's solution under LD (24-hr photoperiod) conditions. Before the culture, the leaf-blade was cut round to an equal size of $10 \mathrm{~cm}$ in diameter. The cuttings were used for experiments after about one week's culture, when they had developed adventitious roots. By this time, the central one of the three axillary

* Supported in part by a grant in aid from the Ministry of Education.

** Biological Institute, Faculty of Science, Tôhoku University, Sendai. 
buds of each cutting had grown into a shoot, but two others showed little or no development. During the experiments under SDs, the former made further growth, while the latter hardly did. The effects of CCC on the shoot growth and on the tuberization or sprouting were examined with the shoot and the two buds mentioned above, respectively. Seven or eight cuttings were employed for each treatment.

LD (24-hr. photoperiod) treatment was given in a glasshouse, natural days being extended with fluorescent tubes and incandescent lamps at the intensity of 400-500 lux. SD (8.5-hr. photoperiod) treatment was performed in a growth cabinet (Koitotron) at $23^{\circ}$. As the light sources, fluorescent tubes and mercury lamps were used, the light intensity being 3500 lux.

Unless otherwise stated, CCC was applied to the nutrient solution in which the basal part, about $10 \mathrm{~cm}$, of the rooted cutting was immersed.

\section{Results}

Effects of CCC on the shoot growth, tuberization and tuber sprouting in the cuttings grown under $S D$ s

Cuttings were kept under SDs, and CCC was applied to the culture solution or to the buds at the beginning of the SD treatment. The bud treatment was carried out as follows. The two axillary buds and the terminal bud of the shoot were covered with absorbent cotton moistened with CCC solution for 12 days, the cotton being renewed every two days.

The results are given in Tables 1 and 2. The former also includes the results of another experiment (Expt. II), in which only the effect of CCC added to the culture medium was tested.

Effect on the shoot growth. As shown in Table 1, CCC retarded the shoot growth. It did not exert appreciable injury to the plant at concentrations up to $3 \mathrm{mM}$, but was more or less toxic at $5 \mathrm{mM}$ or higher.

Effect on tuberization. Table 2 indicates that $\mathrm{CCC}$ at 0.5 and $1 \mathrm{mM}$ accelerated the formation of aerial tubers, although it had little effect on the final size of the

Table 1. Effect of CCC on shoot growth in cuttings subjected to 25 SDs. CCC was applied at the beginning of the SD treatment.

\begin{tabular}{|c|c|c|c|}
\hline Treatment & $\begin{array}{l}\text { CCC conc. } \\
(\mathrm{mM})\end{array}$ & \multicolumn{2}{|c|}{$\begin{array}{l}\text { Shoot length } \\
(\mathrm{mm})\end{array}$} \\
\hline \multirow{7}{*}{$\begin{array}{l}\text { Basal part of } \\
\text { cutting }\end{array}$} & & Expt. I & Expt. II \\
\hline & 0 & 66.9 & 49.7 \\
\hline & 0.5 & 75.6 & 51.8 \\
\hline & 1 & 58.9 & 25.6 \\
\hline & 3 & 16.7 & - \\
\hline & 5 & $11.4^{*}$ & $14.4^{*}$ \\
\hline & 10 & - & $5.3^{*}$ \\
\hline & 0.5 & 60.1 & - \\
\hline Bud & 1 & 45.9 & - \\
\hline & 3 & 26.8 & - \\
\hline
\end{tabular}

* Plants were more or less injured. 
Table 2. Effect of CCC on tuberization and tuber sprouting in cuttings kept under SDs. CCC was applied at the start of the SD treatment.

\begin{tabular}{c|c|ccc|ccc}
\hline \multirow{2}{*}{ Treatment } & $\begin{array}{c}\text { CCC } \\
\text { conc. } \\
(\mathrm{m} M)\end{array}$ & \multicolumn{3}{|c|}{$\begin{array}{c}\text { Tuber stage* } \\
\text { after }\end{array}$} & \multicolumn{3}{c}{$\begin{array}{c}\text { Tuber sprouting (\%) } \\
\text { after }\end{array}$} \\
\cline { 2 - 6 } $\begin{array}{c}\text { Basal part } \\
\text { of } \\
\text { cutting }\end{array}$ & 0 & 0.7 & 3.5 & 8.9 & 0 & 0 & 0 \\
& 0.5 & 0.7 & 4.2 & 9.2 & 0 & 0 & 0 \\
& 1 & 1.0 & 4.8 & 9.4 & 0 & 0 & 38.5 \\
& 3 & 1.0 & 2.8 & 6.2 & 0 & 0 & 20.0 \\
& 5 & 0.5 & died & - & 0 & - & - \\
\hline \multirow{3}{*}{ Bud } & 0.5 & 0.8 & 3.8 & 8.3 & 0 & 0 & 33.3 \\
& 1 & 1.0 & 5.3 & 9.3 & 0 & 25.0 & 58.3 \\
& 3 & 0.6 & 4.1 & 6.8 & 0 & 27.3 & 70.0 \\
\hline
\end{tabular}

* Index to the degree of tuberization ${ }^{10)}$; the larger the figure, the larger the tuber size.

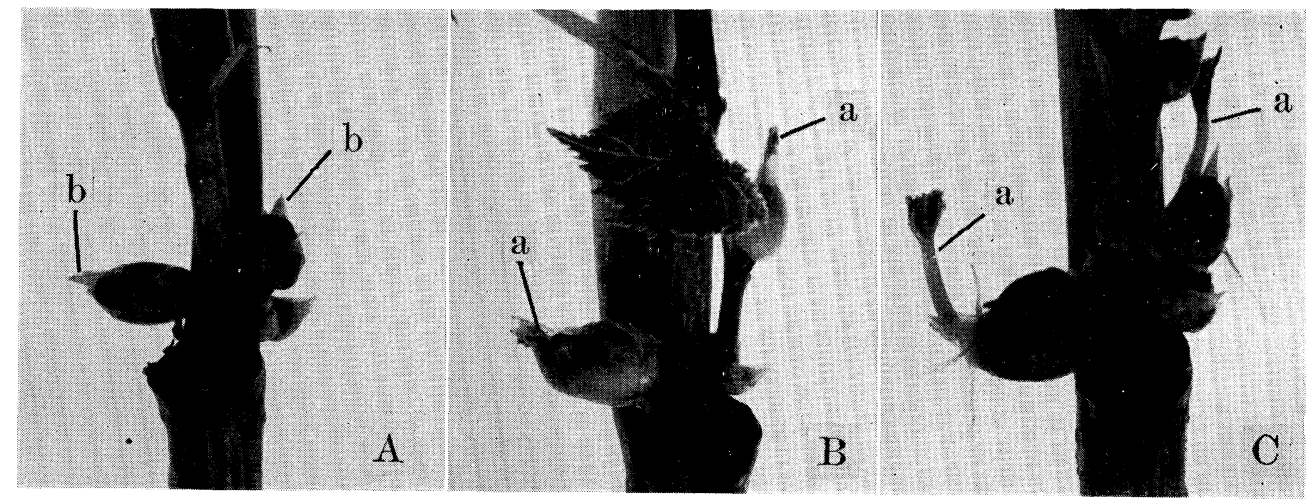

Fig. 1. Effect of CCC $(1 \mathrm{mM})$ on tuber sprouting in cuttings exposed to 25 SDs.

A, untreated control; B, CCC was applied to the culture solution; C, CCC was applied to the buds. a, sprout; b, tip of scaly leaf covering tuber.

tubers. At $3 \mathrm{mM}$, however, $\mathrm{CCC}$ tended to retard the tuberization.

Effect on the tuber sprouting. The results are shown in Table 2 and Fig. 1 . It is a very noteworthy fact that sprouting occurred in some of the tubers formed in the CCC-treated cuttings which were kept continuously under SD conditions. Of course, no sprouting was caused in the untreated controls.

Effect of CCC on the sprouting of tubers formed under a limited number of SDs

Some of the tubers formed by exposing the plants to SDs below a certain number begin to sprout under the subsequent $\mathrm{LDs}^{1,2)}$. The present experiment was made to examine the effect of CCC on the tuber sprouting to be caused under such photoperiodic conditions.

Cuttings were subjected to 12 SDs followed by 13 LDs. CCC $(1 \mathrm{mM})$ was applied varying days after the start of the photoperiodic treatment. The results at the end of the $13 \mathrm{LDs}$ are given in Table 3. CCC remarkably promoted the tuber sprouting. 
Table 3. Effect of CCC $(1 \mathrm{mM})$ on tuber sprouting in cuttings exposed to 12 SDs followed by 13 LDs.

\begin{tabular}{c|c}
\hline $\begin{array}{c}\text { Start of CCC treatment } \\
\text { (Days after start of SD treatmet) }\end{array}$ & Sprouting (\%) \\
\hline Untreated & 13.3 \\
0 & 100.0 \\
4 & 92.8 \\
6 & 100.0 \\
8 & 75.0 \\
11 & 68.8 \\
14 & 31.3 \\
17 & 12.5 \\
\hline
\end{tabular}

Table 4. Effect of CCC $(1 \mathrm{mM})$ on tuber sprouting. Cuttings were given 6 or 12 SDs and then kept under LDs.

\begin{tabular}{c|cc|cc}
\hline \multirow{2}{*}{$\begin{array}{c}\text { Start of CCC treatment } \\
\text { (Days after start } \\
\text { of experiment) }\end{array}$} & \multicolumn{2}{|c|}{6 SDs } & \multicolumn{2}{|c}{12 SDs } \\
& \multicolumn{2}{|c|}{$\begin{array}{c}\text { Sprouting } \\
\text { after }\end{array}$} & \multicolumn{2}{|c}{$\begin{array}{c}\text { Sprouting } \\
\text { after }\end{array}$} \\
& 28 days & 40 days & 28 days & 40 days \\
\hline Untreated & 20.0 & 80.0 & 0.0 & 0.0 \\
0 & 100.0 & 100.0 & 40.0 & 40.0 \\
3 & 91.7 & 100.0 & 50.0 & 78.7 \\
6 & 92.2 & 100.0 & 57.1 & 80.0 \\
9 & 77.8 & 100.0 & 42.8 & 50.0 \\
12 & 20.0 & 100.0 & 0.0 & 40.0 \\
\hline
\end{tabular}

The early CCC treatment produced more striking effect than did the late treatment.

The above results were corroborated by the next experiment, in which the cuttings given 6 or 12 SDs were subsequently kept under LDs and examined for sprouting 28 and 40 days after the beginning of the SD treatment (Table 4).

\section{Concluding Remarks}

It has been shown that $\mathrm{CCC}$ and some other growth retardants inhibit GA biosynthesis in Fusarium moniliforme $e^{11-13)}$, and evidence is accumulating that the same seems to be true also in the case of higher plants ${ }^{13-17}$, although there may be other modes of action of these chemicals as discussed by Cleland ${ }^{18}$. If the endogenous GA level in the CCC-treated cuttings was actually lowered in our experiments, though we have not tested this as yet, the results described above favour the supposition offered in the introduction of this paper.

Firstly, the fact that the tuber formation under SDs is accelerated by CCC treatment is compatible with the view that the lowering of the native GA level is necessary for tuber initiation. However, the possibility may not be ruled out that $\mathrm{CCC}$ accelerates tuberization by reducing the native auxin content or by antagonizing the auxin action, because 1 ) it has been revealed that the endogenous auxin level in 
Begonia leaves falls at first under SDs and that auxin treatment at this stage inhibits tuberization $^{19)}$, and 2) there have been several experimental results which afford evidence to support the possibility that the growth retardants affect some aspect of the auxin metabolism in higher plants (see Cleland ${ }^{18)}$ and Khan and Tolbert ${ }^{20)}$ ).

Secondly, CCC treatment not only promotes the tuber sprouting in the cuttings subjected to a limited number of SDs, but also causes the tubers to sprout eventually in the cuttings kept continuously under SDs. This supports the supposition that the increase in amounts of the endogenous GA is responsible for the induction of tuber dormancy.

As to the mechanism by which GA induces dormancy, we have found that the amount of some growth inhibitor(s) which is considered to take part in the induction of tuber dormancy increases in the tubers by treating them with $\mathrm{GA}^{8,21}$, and we have obtained several pieces of information on the enzyme system participating in the formation of the inhibitor ${ }^{22)}$. Details of these results will be published elsewhere.

\section{Summary}

The effect of (2-chloroethyl)trimethylammonium chloride (CCC) on the formation and dormancy of aerial tubers in Begonia evansiana was investigated. CCC was applied to the nutrient solution in which the rooted cuttings were grown, or directly to the buds.

CCC accelerated the tuber initiation under SD conditions, and prevented the tubers from entering a dormant state.

If we assume that CCC has actually lowered the native GA level, the present results would suggest that the endogenous GA is one of the factors controlling the tuber initiation and tuber dormancy in this plant, the view which has been advanced on the basis of the experiments with exogenous GA.

\section{References}

1) Esashi, Y., and Nagao, M., Sci. Rep. Tôhoku Univ. Ser. IV (Biol.) $24: 81$ (1958). 2) Esashi, Y., ibid. 27: 101 (1961). 3) Esashi, Y., and Nagao, M., ibid. 25: 191 (1959). 4) Brian, P. W., Biol. Rev. Cambridge Phil. Soc. $34: 37$ (1959). 5) Stowe, B. B., and Yamaki, T., Science 129 : 807 (1959). 6) Nagao, M., and Mitsui, E., Sci. Rep. Tôhoku Univ. Ser. IV (Biol.) 25 : 199 (1959). 7) Okagami, N., Esashi, Y., and Nagao, M., Proc. 26th Ann. Meet. Bot. Soc. Japan, 37 (1961). $\quad$ 8) Okagami, N., Esashi, Y., and Nagao, M., Proc. 5th Symp. Jap. Soc. Plant Physiol., 66 (1964). 9) Okagami, N., unpublished data. 10) Esashi, Y., Sci. Rep. Tôhoku Univ. Ser. IV (Biol.) 26 : 239 (1960). 11) Kende, H., Ninnemann, H., and Lang, A., Naturwiss. 50 : 599 (1963). 12) Ninnemann, H., Zeevaart, J. A. D., Kende, H., and Lang, A., Planta 61 : 229 (1964). 13) Harada, H., and Lang, A., Plant Physiol. $40: 176$ (1965). 14) Baldev, B., and Lang, A., Am. J. Bot. 52: 408 (1965). 15) Baldev, B., Lang, A., and Agatep, A. O., Science 147: 155 (1965). 16) Paleg, L., Kende, H., Ninnemann, H., and Lang, A., Plant Physiol. 40 : 165 (1965). 17) Zeevaart, J. A. D., Plant Physiol. 40 (suppl.) $1 \times x v$ (1965). 18) Cleland, R., Plant and Cell Physiol. 6: 7 (1965). 19) Esashi, Y., Eguchi, T., and Nagao, M., ibid. 5: 413 (1964). 20) Khan, A.A., and Tolbert, N.E., Physiol. Plant. $19: 81$ (1966). 21) Okagami, N.. and Nagao, M., Proc. 28th Ann. Meet. Bot. Soc. Japan, 100 (1963). 22) Okagami, N., and Nagao, M., Proc. Ann. Meet. and 6th Symp. Jap. Soc. Plant Physiol., 92 (1965). 
摘 要

長尾昌之・岡上伸雄：シュウカイドウ地上塊茎の形成・休眠におよぼす

(2-クロロエチル) トリメチルアンモニウムクロライド (CCC) の影響

発根させたシュウカイドウ切枝にジベレリンの生合成を阻害するといわれているCCC を与え，これが地 上塊茎の形成・休眠におよぼす影響を調べた。CCC は培養液または芽に与えた。CCC 処理は短日下での塊 茎形成を促進し，塊茎が休眠に入ることを抑制した。この紹果は，ジベレリン処理の実験からわれわれが得 ている見解, 寸なわち体内ジベレリン含量が塊茎の形成・休眠の誘起を左右する一要因であるという推測を 支持する.（東北大学理学部生物学教室) 